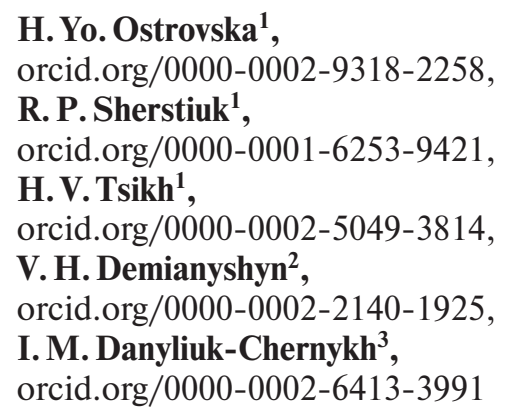

1 - Ternopil Ivan Puluj National Technical University, Ternopil, Ukraine, e-mail: h.ostrovska@gmail.com

2 - Western Ukrainian National University, Ternopil, Ukraine 3 - Ivano-Frankivsk National Technical University of Oil and Gas, Ivano-Frankivsk, Ukraine

\title{
CONCEPTUAL PRINCIPLES OF LEARNING ORGANIZATION BUILDING
}

Purpose. Methodological and applied principles deepening, recommendations projecting due to learning organizations building, in order to obtain fundamentally new competitive advantages in a knowledge-based economy.

Methodology. The development of theoretical and methodological foundations of learning organizations building should be carried out on the basis of provisions synthesis of neural networks theory and the latest management paradigm with a projection on staff development; theories of personality and its development in activity; sociology, motivation, theory of organization and competitive advantage, chaos theory and synergetic.

Findings. Priorities of learning organizations building in a knowledge-based economy is developed is defined. The own vision of learning organization building conceptual bases as a fundamental component of competitiveness management system on the bases of innovative development is formulated. A new understanding of "learning organization" category essence is proposed. Learning organizations formation principles, which are based on the latest enterprise management paradigm are improved. The study actualizes the value of educational and human capital, as well as proves their impact upon the socio-economic development of the organization. Emphasis is placed at the fact that the activities of learning organization are based on the culture, system and skills of learning. It is proved that the transformation of domestic enterprises into learning organizations will avoid many problems of the nonlinear world picture and accelerate the processes of effective management at each enterprise.

Originality. The work develops the conceptual principles of learning organization building, the representation of which is reproduced according to the original conceptual-analytical model in distinguishing its architecture on the basis of innovative development. The model of learning organization is presented, the novelty of which is to systematize and clarify the requirements for the basic elements of the organization and to reflect the relationships between them. The mechanism of creation and use of knowledge of the learning organization is developed. It will increase its competitiveness from the standpoint of strategic approach and expand competitive positions in the market.

Practical value. The practical use of scientific developments and recommendations of the authors allows to increase the innovation and efficiency of the national innovation system structure-producing organizations.

Keywords: innovative development, learning organization, lifelong learning, intellectual potential, human capital, knowledge management

Introduction. The focusing of modern economics on the formation, development and implementation of basic learning organizations conceptual provisions points is due to the latest processes in the business environment, in particular: the formation of a knowledge-based economy; intensification of business entities restructuring processes; effective use of intellectual potential and accumulation of intellectual capital in enterprises; the conceptual foundations of strategic planning revision, etc. Analysis of business practices confirms that the inability to adapt in a turbulent competitive environment leads to the fact that more than $70 \%$ of start-up enterprises do not exceed two years of existence, and about $5 \%$ - five years. In our opinion, the solution of these problems should be connected with the high professional competence of top management and staff, their constant development and creation learning organizations and their transformation into innovative ones on this basis. According to D. Bersin, "companies must appropriate the requirements of the business ecosystem. By teams strengthening, creating a new management model and developing an updated and expanded leadership structure organizations recreate themselves, paving the way for innovation, competition and prosperity" [1]. In this context successful and very relevant in theoretical and practical terms seems interesting and very relevant the statement that in the age of the knowledge-based economy only those companies that can truly transform from industrial enterprises into learning organizations. The new para-

(c) Ostrovska H. Yo., Sherstiuk R. P., Tsikh H.V., Demianyshyn V.H., Danyliuk-Chernykh I. M., 2021 digm of activity interprets them as "smart" enterprises or those that are able to develop management of knowledge.

The practical experience of leading corporations convinces that human resources are the most important factor of productivity and investment goals, management of changes is the main goal of management. This emphasis is logically associated with changes management and the organization flexibility managing problem natural solution in a dynamic competitive environment.

Literature review. The problems of learning organizations (The Learning Organization) creation and functioning stood out in 1950s within the organistic and socio-technical systems approach versions in the context of the organization as a social organism vision. Active research of learning organizations aspects began in the 80-90s of the twentieth century - in the period of outlining the signs of the knowledge-based economy formation. In this context, one of the first works was the famous book "A Behavioral theory of the firm" (Cyert, March, 1963); a significant contribution to the organizational learning development was made by the well-known works "Organization Learning" (Argyris, 1976) and "Theory in Practice" (Shon, 1983). However, the undisputed leaders are P. Senge's books "The Fifth Discipline: The Art \& Practice of The Learning Organization" (Senge, 1990) and "The Dance of Change" (Senge. et al., 1999). In the future significant work on this issue can be divided into three areas: learning as improving of own knowledge (Nonaka, Takeuchi, 1995), a dynamic approach to the development of organizational skills (Prahalad, Hamel, 1990) and chaos theory (Stacey, 1992). Modern foreign and domestic researchers who crystallize the 
learning organization theory development are such as: A. Örtenblad [2], G. Fillion, V. Koffi, and J. P. B. Ekionea [3], V. Heyets and A. Gritsenko [4], O. Romanovskyi [5], L. Shevchenko [6], and others. However, the issue of building a learning organization remains relevant due to the lack of system and methodological support during its consideration.

Methods. The most correlated with this rather new scientific problem we consider organizational renewal theory of G. Lippi; self-renewal theory of J.Gardner; organizational learning theory of K. Argyris. In this context, the concepts of: organizational development and organizational culture of K. Levin and E. Shane deserve an attention; the organization innovative development of I. Nonaka; educational systems of D. Shon; talent management based on genius theory of T. Sheff; as well as the concept of the knowledge-based organization - the intellectual and learning organization (P. Senge, T. Bazan, J. Quinn, D. Garvin, M. Rubinstein, etc.). Research methods: general scientific methods of cognition, system approach, comparative and economical-statistical analysis, sociological research methods.

Results. The modern socio-economic system of Ukraine requires serious modernization by strengthening the intellectual and innovative components of economic commercial activities agents, which will promote both the development of business entities and national interest adaptation to the knowledge-based economy globalization. This approach requires shifting the emphasis on investment priorities at all levels of management, identifying the development of human capital as the most important strategic priority of the state investment policy, which should be considered as a major factor in the competitiveness of domestic businesses and the country as a whole. Taking into account the main trends of modern management and practical experience of successful companies allowed to state that the optimal change of domestic enterprises is their transformation into learning organizations as a necessary condition for economic synergy and implementation of innovation breakthrough strategy [7]. The functioning of such organizations as subjects of the national innovation system will contribute to the development and growth of this system efficiency as a knowledge integrator.

Analysis of theoretical sources, practical failures and achievements of business structures confirms the fact that in attempts to implement an innovative model of development, to build a learning organization is dominated by one-sided and fragmentary approaches. A system approach in the context of building a learning organization should be based on interdisciplinary principles using the results of research in management, psychological and sociological sciences, a combination of marketing and resource approaches in management, taking into account trends in knowledge-based economy. This approach, of course, is relevant, predictive and promising for the development of modern science.

Building a self-learning organization aims to create the conditions for successful operation in a constantly changing competitive environment, provided the transition to the status of an innovative enterprise. From this perspective, the most important task for a learning organization is to ensure the ability of its employees to systematic learning for the development of knowledge, and self-improvement for the formation of new competencies. Under the concept of learning organization, we understand a system of views that substantiate the way this organization receives fundamentally new competitive advantages, and the implementation of this approach will contribute to the formation of corporate culture and accelerated transition to innovative development in a knowledge-based economy. At the same time, the innovative development of a learning organization is based on a policy aimed at the effective use of intellectual potential that can ensure the continuous flow of value creation processes.

According to the concept, a well-established system of constant learning in the organization allows to achieve integrity and consistency in learning, contributes to the building of a creative environment and the formation of new competencies on this basis. In addition, this system allows the organiza- tion's staff to perform all activities at a qualitatively new level and to form new functions of the organization, such as: identifying new opportunities for future development, coordinated interaction of all system elements to achieve the desired future state, achieve synergy effect. Accordingly, the unity of economic activity and staff training defines the organization as a systemic whole, while transforming its essential characteristics (in particular, the formation of a knowledge culture that affects the company ability to create its fundamental values).

In a conceptual sense, it is necessary to agree with the interpretation of learning as the sum of program (information) learning and organizational learning, in other words, learning in action by asking and discussing issues, obtaining confirmations based on generalization of practical experience. Of course, the biggest reserve for staff development and creativity and initiative is the second component of learning, and its implementation is facilitated by the organization of staff various categories collective learning, which intensifies the dissemination of knowledge and their transformation into the organization as a whole. Thus holistic training promotes intellectual, psychological, spiritual growth of the person by transformational processes in the organization, and as a result of its effective functioning in the conditions of technological development.

According to the concept, a learning organization must provide: firstly, a high level of all intellectual skills development. They are of paramount importance the capabilities such as receiving, storing, converting and issuing information; development of new knowledge; making rationally reasonable decisions; formulation of goals and activities control to achieve them; assessment of situations arising in the environment; learning, development, adaptation. This level can vary greatly from enterprise to enterprise. Thus, there is a second level of such abilities, which is qualitatively different: it is learning (double-loop learning), adaptation (adaptability), decision-making and formation of new knowledge (creation of meta-knowledge, meta-learning), control (control to control), which are characteristic exactly to learning organizations. Secondly, the high level of socio-cultural qualities at which learning organizations pay considerable attention to solving moral, cultural, social issues and assess the consequences of their actions in the long term.

Thus, specified organizations have a high potential for obtaining, analyzing, interpreting and using information, which ultimately allows you to accumulate new knowledge, produce new hypotheses, ideas and ways to implement them. In this case, the immanent property of the organization is the value-semantic vector of humanistic creation, as well as learning quality.

The logic of our research requires the development of basic principles for building a learning organization that will ensure the achievement of this goal. In this context, we propose to use the principles of learning organizations formation proposed by P. Senge [8]: improving the skills of the individual (personal mastery); creating a common vision; team learning; identification of mental models; systems thinking. In our opinion, in the formation of a learning organization these principles are fundamental. At the same time, they need to be added, given the lack of alternatives for the innovative development of domestic enterprises in the conditions of knowledge-based economy formation. New (or additional) principles, based on the latest paradigm of enterprise management, allow to expand the capabilities of learning organization:

- use of society informatization and intellectualization rapid process, which will allow to form an effective information network for rapid response to changes in the competitive environment;

- solving the problem of minimizing noise - information deformers through the optimization of information flows;

- focusing on the time factor. The concept of learning organization makes it possible to predict the ability of market participants in the context of the implementation of preventive management decisions;

- creating the organization variability atmosphere. Volatility means the ability of organization as the open system to trans- 
form any type, striving to maintain a flexible dynamic balance within a single whole, based on adaptation or advanced development through the mechanisms of self-identification, selfdevelopment and integrativeness. The tendency to adapt or anticipate development of variability various forms depends on the competence of management;

- making a mechanism for overcoming the concept of «collective memory" by prioritizing horizontal links between units. The architecture of the creative network has the ability to excite or inhibit the activity of its individual parts;

- competence of communication, which is aimed at developing the ability to understand, assimilate and share knowledge.

In this context, we note that successful are those businesses entities that use the principles of learning organization systematically and at all levels of management.

The key structural elements of a learning organization are the intellectual potential of employees, the knowledge management system and the basic elements of organization, each of which should contribute to the effective functioning of other components (Fig. 1).

According to the model, the knowledge management system and the basic elements of the organization contribute to the development and use of intellectual potential of employees. In these conditions, the knowledge management system should be based on a cultural and value approach and, in order to increase the effect of organization intellectual activity, based on the principles of quality management. In turn, the effective use of highly developed intellectual potential at different stages of the innovation process through research, implementation of research and development in production, or the involvement of other competent (interested) structures ensures the continuity of the innovation process and the ability to eliminate the so-called innovation gap.

According to this vision, a learning organization will be a creative humanistic-oriented organization that actively involves into the innovation process intelligence - knowledge and experience of employees, partners, customers, and creates an environment for effective development and use of intellectual potential to ensure continuity of innovation and creation dynamic latent competitive advantages of this organization in a turbulent operating environment.

The model representation of a learning organization explains that it develops through continuous training and learning of employees, and each member of its team is interested in individually improving their own professional level. Herefrom - an organic combination of two learning circuits, the

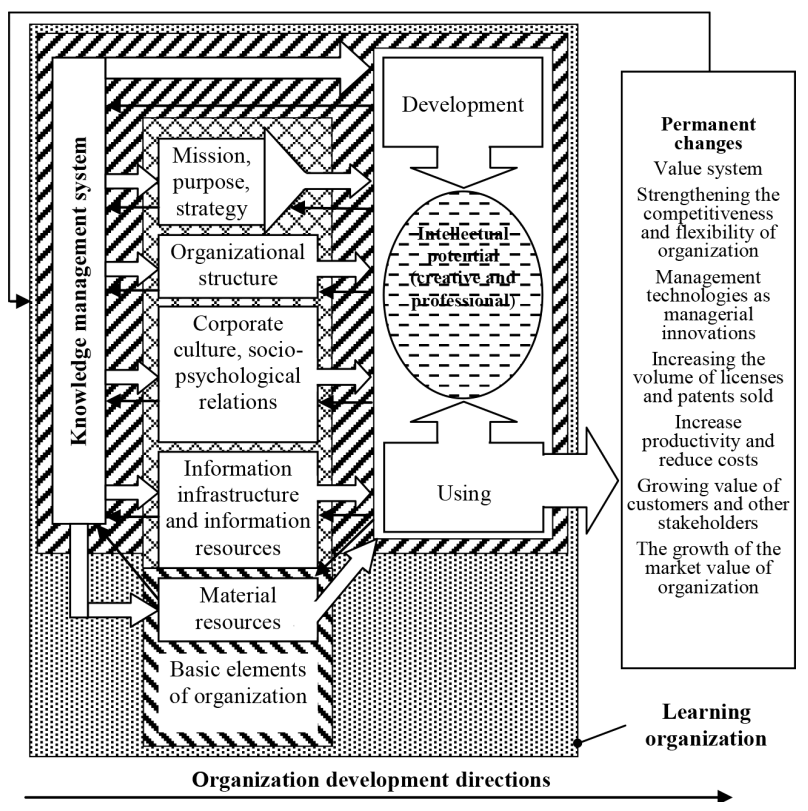

Fig. 1. Model of learning organization so-called double-loop of learning: the first circuit is the organization of compulsory staff training; the second circuit is the creation of staff motivation system for learning. It is believed that the first circuit is implemented without much effort and cost, because it is about educational technologies that can increase the efficiency of each unit. With the transition to the second circuit, resistance to change increases, due to the desire and ability of staff to use the acquired knowledge in practice and share useful information with colleagues.

Continuity of education is one of the most important principles, which gives an individual the opportunity to constantly deepen the general level of education and the level of professional training. In the context of the issue "economic education should be targeted at the target social groups of potential demand, as well as meaningfully aimed at forming key segments of economic culture, such as: work culture, management culture, entrepreneurial culture, business culture, consumption culture, financial behavior culture, etc." [4]. Accordingly, enterprises leaders are increasingly reconsidering their attitudes to education and recognizing the need to invest in human capital, which in the new economy is becoming a critical factor in the competitiveness of businesses. World practice confirms that a $10 \%$ increase in the level of education provides an increase in labor productivity by $8.6 \%$, while a similar increase in share capital - only 3-4\% increase in labor productivity. That is why in developed countries economically active people are engaged in mental activity in particular, in the US this figure is $85 \%$ of total employment growth, in the UK $-95 \%$, in Japan - $90 \%$, in Germany - $89 \%$. Today, "white-collar" and/or "golden-collar" in the United States account for more than $70 \%$ of the working population and receive more than $80 \%$ of the payroll [9]. Given the fact that the level of education has the greatest impact upon the development of creative competencies, we emphasize the need to reform training methods in Ukraine, namely changes in the education system in the context of reorientation to innovation and constructiveness, in other words - the transformation of "baggage of knowledge" in "capital of knowledge".

Adherence to the professional education continuity principle means the transfer of the "gravity center" of the educational process to the enterprise, which in a knowledge-based economy should become a learning organization [8]. The process of education and production integration can be carried out, according to experts, in the following areas: planning the structure of training on the basis of determining the need for relevant specialization personnel, taking into account the forecast qualifications and competencies; development of curricula and programs that take into account regional features and features of specific jobs (positions); long-term cooperation in all kinds of practice conducting; participation in joint contractual research works with active involvement of students in their implementation; involvement of specialists-practitioners to participate in the educational process. In such cases a contingent is created for personnel leasing, which in the form of temporary employment is developing intensively abroad. Intensified freelance further learning is also possible in this context. Educational technologies that provide mandatory learning for staff in the organization are somewhat similar to those used in education. However, effective mechanisms for the educational institutions and enterprises integration in this area have not yet become systemic. The system of continuous learning and staff development in a learning organization helps to identify the intellectual potential of employees, sublimating it into intellectual capital and the ability of the organization to generate innovations (Fig. 2).

The formation of a learning organization implies the creation of innovation management system based on the activation of organizational knowledge. Thus, specialists in strategic management explain the success of Japanese companies by skill, which is the ability to form new knowledge and implement it into the process of production, provision of services, in the pro- 
cess of their own system development. Unfortunately, streamlining the work with organizational knowledge at most Ukrainian enterprises is reduced to the replacement of innovative development by imitation, in which it is not the generation and application of new knowledge, but the copying of best practices. In this context, the necessary conditions for the successful implementation of organizational knowledge transformation processes are as follows: 1) integration of work processes with new knowledge into the social structures of the organization by increasing horizontal links; delegation of powers; introduction of new rules and procedures for staff interaction, mutual coordination of departments actions and individual employees; 2) increase of innovative activity as a result of all personnel associations types support for the purpose of knowledge exchange; 3) formation and expansion of knowledge dissemination channels system for the among the social system elements, as well as the introduction of a corporate portal at the Smart Enterprise level. It should be noted that increasing the level of organizational knowledge promotes the development of economic thinking (critical, progressive, with restorative potential) based on a competent understanding of socio-economic processes, forms economic consciousness, changes the value field, expands adaptive, integrative, creative and innovative opportunities.

However, in the system of continuous learning and staff development, the issue of formalizing knowledge remains debatable. An effective mechanism for formalizing corporate knowledge can be a learning center. Under the learning center we understand the platform of the organization interaction with other economic agents, consulting companies, educational institutions, professional associations in the direction of the corporate system of learning and development common projecting. In foreign experience, such a transformation of the learning center has become widespread on the basis of corporate universities, which are becoming a continuously operating "staff raising pipeline". Creating a system of corporate education, based on the principles of technology, can be considered as an important and, of course, promising work area of an organization that is interested not only in survival but also in innovative development.

The realities of modernity, in terms of transition to a new educational paradigm and innovative teaching methods, re-

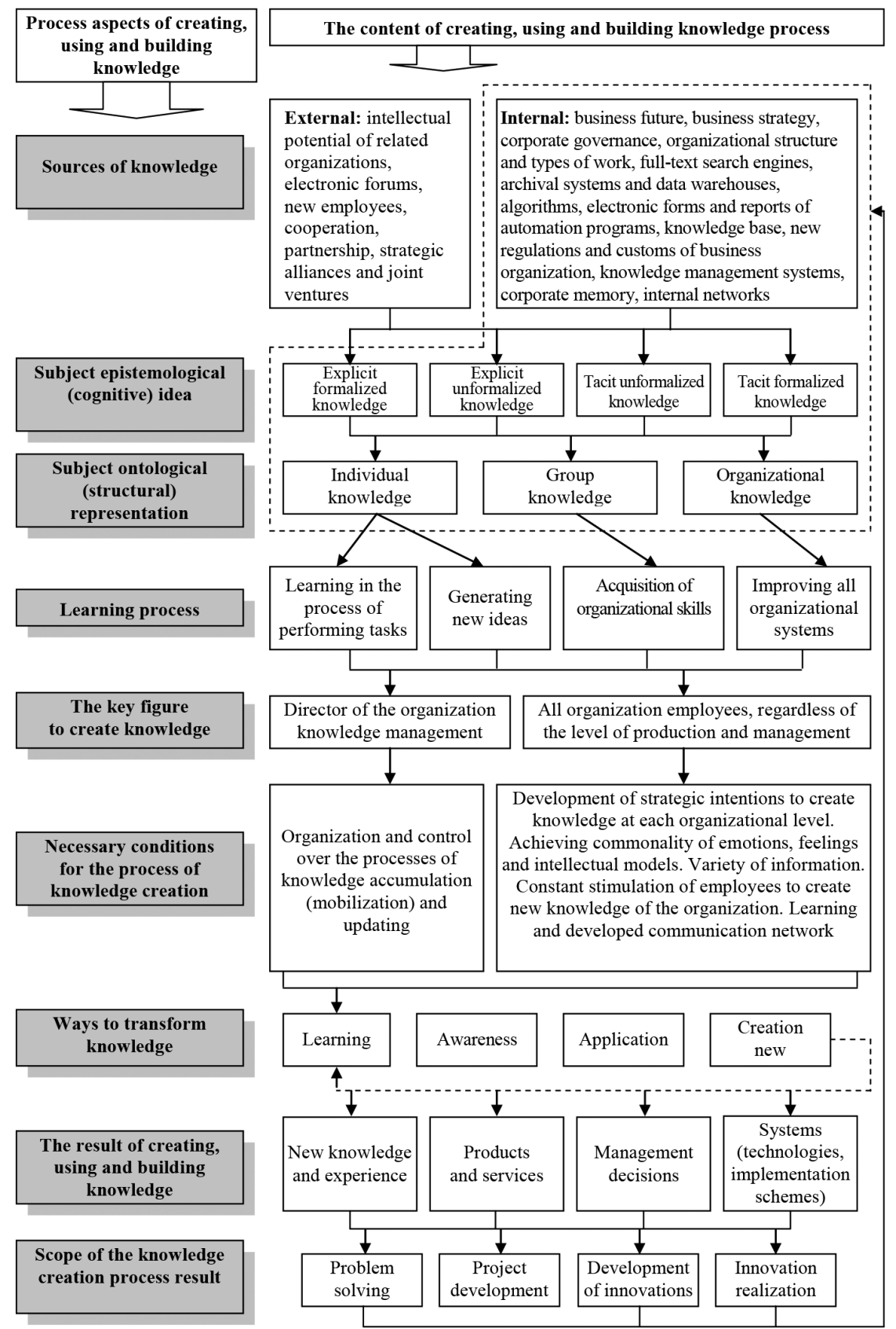

Fig. 2. The mechanism of learning organization knowledge creation and use 
quire conceptual approaches to the formation of entrepreneurial competencies of learning organization. According to research, we note that in the corporate sector for decades, strategic alternatives aimed primarily at minimizing production costs, material resources, technological innovation have been used. In a knowledge-based economy, such positional strategies should take into account the complex social capabilities of the organization and focus on the priority of human resources. The implementation of these ideas, formed on the basis of competitive advantages resource representation, allows strengthen the dynamic component of these advantages, based on knowledge management and corporate culture. Thus, the overall strategy, which is based on identifying, developing and purposefully realizing the potential of key competencies, is not only a simply successful company effective strategy, but also a super-effective strategy for modern leading companies. In this case, the priority object of management are the competencies of employees. Experts of leading companies rightly believe that in a strategic perspective, innovations aimed at developing human potential, values, abilities (human skills) are given priority over innovation in the context of improving product properties, technology and production organization (technical skills). Thus, human resources are the most stable source of competitive advantage, and human resource management know-how is the most reliable and secure. Improving the level of the employee creative competence, which is formed due to the high cognitive resilience of a person and the tendency to non-standard thinking, is the most important factor in ensuring abrupt qualitatively new, progressive changes in the functioning of domestic enterprises, as all sources of "economic breakthrough" already, unfortunately, exhausted. At the same time, an effective motivational environment allows to form a continuous flow of effective innovations to improve the organization activities.

The analysis of world experience shows the fact that the behavioral school of management theoretical and applied principles are the most relevant and reflect significant research and positive results in the context of building exclusive competitive advantages. Examining this issue, we can say that this trend will continue for a long period, and the connection with psychology and sociology is possible in the perspective of motivating employees in the learning organizations formation.

Motivational arguments for learning are: rational - profit from additional training, increasing self-worth in the labor market - that is what the organization management emphasizes to employees who resist learning, and emotional - is the daily efforts of management, coaching, personal example, creation the atmosphere conducive to development. According to the European experience, the professional level of employee organizations needs to strengthen the motivation to acquire and develop new "creative" competencies and accommodation for change (over $65 \%$ of organizations); organization of learning and practice for technical staff (over $45 \%$ of organizations); basic programs and qualifications (over $25 \%$ of organizations); university employees (over $10 \%$ ). Priorities in the field of improving staff motivation to acquire new professional qualifications are concentrated in Finland $(90 \%)$, Germany (over $80 \%$ ), Sweden (over $70 \%$ ), France (about $50 \%$ ), Portugal, Italy, Greece (over $50 \%$ ). Attention is focused on improving the learning and practice of technical staff, namely: in Germany (about $60 \%$ ), Belgium (57\%), Spain, Portugal (more than $40 \%$ ). At the same time, most European companies $(83 \%)$ provide their employees with various forms of professional development every $3-5$ years, spending from 2 to $10 \%$ of the annual salary fund for this process [10]. Let's show that Ukrainian employers are attracted by the use of cheap labor, therefore, cost savings and less interested in the return from investment in training, because it has got a long-term effect.

Noteworthy is the European practice, where in organizations the range of working days set aside for training is concentrated in the range from 1 to 12 . At the same time, in some countries the time spent on training the company staff per year significantly ex- ceeds the average value (11\%), in particular in the UK - 21 working days per employee, in Portugal - more than 20, in Italy more than 19, in Ireland - more than 14, Luxembourg - almost 12 working days. The lowest values of this indicator are observed in Finland - less than 4 working days, in Denmark and Germany - almost 6 [10]. The implementation of the program "education and training" of employees in domestic organizations is proposed to be carried out in stages: firstly, to introduce into practice the range of working days per year devoted to training and education - up to 6 working days per employee; secondly - a gradual increase in working time - up to 12 days; thirdly - more than 12 days, adhering to the conditions of establishing partnerships between the two sectors: education, science and business.

In view of the above, to ensure an effective system of staff professional development motivation, measures are needed to solve the identified problems (quality PR, "effect" of competition, professional advancement, delegation), as well as measures that generally increase the desire to acquire professional knowledge and skills, to improve work results (individual approach, use of bottom-up initiative, development of an informative Internet portal, application of a bonus system for training). In this context, in addition to the above measures, in our opinion, a number of motivational "drivers" are needed - specific tools that increase motivation to learn, among which the most effective: the availability of managers support for learning; active participation of employees in learning plans preparation process; practicality and demand for the acquired knowledge and skills; promotion of professional learning at the enterprise; recognition of employees who have achieved high results; creation of a vocational learning portal.

Foreign experience in today's conditions emphasizes the importance of knowledge exchange processes motivation. In practice, there is a close relationship between the effectiveness of knowledge sharing processes and the system of staff motivation.

In the process of the economy transition to the knowledge era, the main role in the formation of a learning organization and its sustainable competitive advantages acquisition is played by leadership. Leadership in a learning organization is first and foremost a tool for change management. P. Drucker argues that the success of an organization is $80 \%$ dependent on organizational leadership, and its disintegration comes primarily from incompetent leadership [11]. Continuing the vector of research, we will clarify the requirements of today's practice for the organizational leadership theory. The first requirement arises according to the new laws of organizations functioning, under which there is a need for heads of new type. The second requirement can be formulated as follows: the need for a scientifically reasonable model of organizational talent has sharply increased in recent years due to the fact that at the present stage of organizations development in advanced countries is no longer the task of effective management. Today, the main problem is whether the leader is really a recognized organizational leader, or he is endowed with the talent of the successful organization creator for the future. The third requirement is dictated by changing the process of social transformation. According to the laws of synergetic, these transformations translate the social system from a stable state to a state of bifurcation, which can lead either to a new leap in social development or to a catastrophe. One of the main attracting mechanisms that contribute to the development of social systems is a "new type of leader" appearance. And if in the past social transformations were relatively slow, investing in several generations, which sharply increased the possibility of spontaneous emergence of a talented organizational leader, today radical social transformations have fundamentally changed the dynamics of the need for organizational leaders. The fourth requirement is due to the intensification of competition, which is becoming increasingly complex, sophisticated forms. In this regard, most experts in the field of organization management recognize that, both in terms of security and reliability, and for economic reasons and moral positions, to maintain and strengthen the corporate spirit is more profitable to "grow" their leaders, given acme-psychological 
support to personality development of a talented leader at all stages of the organization life cycle. Thus, in order for organizations to function and develop successfully in these conditions, there is a need to design and create social institutions that are dedicated to purposefully reproduce leaders who are able to inspire lasting spiritual and social transformations.

Conclusions. Based on the outlined dominant of enterprises socio-economic development, the necessity is substantiated and the own vision of learning organization conceptual principles as a fundamental component of the intellectual potential management system is formed. In this context, the implementation of the formulated concepts will create conditions for building a learning organization that will have a number of new competitive advantages and will form the basis for its transformation with a priority innovative direction of development. This organization acquires new features, namely: the overall vision is formed by its individual members, personal vision is related to organizational, while organizational vision and mission change as a result of self-learning and constant learning; individual learning becomes a collective way of dialogue, requires the encouragement and acceptance of corporate culture and corporate structure, which are supported by the organization; where there is a well-balanced combination of skills and development-oriented learning, which includes a culture that encourages and supports learning, with flexible structures that have the potential for change (to support future learning); employees use systems thinking to identify and solve problems. This team, united by a common vision and values, is able to develop, improve the production process (the product of this process), the relationships that develop during this process, as well as their understanding of the situation through constant feedback from colleagues, customers, partners, managers, that is external and internal environment.

Implementation of the learning organization formulated concept will increase competitive advantages in the domestic and world markets from the standpoint of a strategic approach, as it involves the competencies dynamic models formation based on effective use of intellectual potential and provides high flexibility and predictable adaptability to changing market environment.

\section{References.}

1. Global Human Capital Trends 2016 (2016). Deloitte University Press. Retrieved from https://www2.deloitte.com/ua/uk/pages/human-capital/articles/introduction-human-capital-trends-2016.html. 2. Örtenblad, Anders R. (2020). The Oxford Handbook of the Learning Organization. Oxford University Press.

3. Fillion, G., Koffi, V., \& Ekionea, J. (2015). Peter Senge's Learning Organization: A Critical View and the Addition of Some New Concepts to Actualize Theory and Practice. Journal of Organizational Culture, Communications and Conflict, 19(3), 73-102.

4. Geyets, V. M., \& Gritsenko, A. A. (Eds.) (2019). Socio-class transformations and formation of a new quality of education as components of the reconstructive development of the economy of Ukraine. Kyiv: NAS of Ukraine, SI "Inst. of Economics and Forecasting of the NAS of Ukraine". Retrieved from http://ief.org.ua/docs/scc/11.pdf.

5. Romanovskyi, O. O. (2015). Development of academic entrepreneurship and entrepreneurial higher educational institutions in conditions of globalization. Efficient economy, 11. Retrieved from http:// nbuv.gov.ua/UJRN/efek_2015_11_17.

6. Shevchenko, L. S. (2016). Mergers and Acquisitions in Higher Education. Actual Problems of Economics, (11), 160-167.

7. Ostrovska, H. (2018). The strategy of innovative-technological breakthrough of industrial enterprises into the European economic area through the effective use of intellectual potential. Socio-Economic Problems and the State, 19(2), 95-113.

8. Senge, P. (2018). The Fifth Discipline: The Art \& Practice of The Learning Organization. Moscow: Mann, Ivanov and Ferber.

9. Made Smarter Review (2017). Retrieved from https://assets.publishing.service.gov.uk/government/uploads/system/uploads/attachment data/file/655570/20171027_MadeSmarter_FINAL_DIGITAL.pdf. 10. Sobko, O. M. (2016). Intellectual capital and creation of enterprise value: monograph. Ternopil: TNEU. Retrieved from http://dspace. wunu.edu.ua/handle/316497/22515.
11. Drucker, P. (2020). Management Challenges for the $21^{\text {st }}$ Century. KM-BOOKS

\section{Концептуальні засади побудови самонавчальних організацій}

\author{
Г. Й. Островська ${ }^{1}$, Р. П. Шерстюк ${ }^{1}$, Г. В. Ціх ${ }^{1}$, \\ В. Г. Дем'янишин ${ }^{2}$, I. М. Данилюк-Черних ${ }^{3}$
}

1 - Тернопільський національний технічний університет імені Івана Пулюя, м. Тернопіль, Україна е-mail: h.ostrovska@gmail.com

2 - Західноукраїнський національний університет, м. Тернопіль, Україна

3 - Івано-Франківський національний технічний університет нафти і газу, м. Івано-Франківськ, Україна

Мета. Поглиблення методологічних і прикладних засад та розроблення рекомендацій щодо побудови самонавчальних організацій з метою отримання принципово нових конкурентних переваг в умовах економіки, заснованої на знаннях.

Методика. Розвиток теоретико-методологічних основ побудови самонавчальних організацій доцільно здійснювати на базі синтезу положень теорії нейронних мереж і новітньої парадигми управління із проекцією на розвиток персоналу; теорії особистості та іiі розвитку в діяльності; соціології, мотивації, теорії організації й конкурентних переваг, теорії хаосу та синергетики.

Результати. Визначені пріоритети побудови самонавчальних організацій в умовах економіки, заснованої на знаннях. Сформульоване власне бачення концептуальних засад побудови самонавчальної організації як основоположної складової системи управління конкурентоспроможністю на засадах інноваційного розвитку. Запропоноване нове розуміння сутності категорії «самонавчальна організація». Удосконалені принципи формування самонавчальних організацій, що грунтуються на новітній парадигмі управління підприємством. Дослідження актуалізує цінність освіти й людського капіталу, а також доводить їх вплив на соціально-економічний розвиток організації. Акцентована увага на тому, що діяльність самонавчальної організації грунтується на культурі, системі й навичках самонавчання. Доведено, що трансформація вітчизняних підприємств у самонавчальні організації дасть змогу уникнути багатьох проблем нелінійної картини світу та прискорити процеси ефективного управління на кожному підприємстві.

Наукова новизна. У роботі розвинуті концептуальні засади побудови самонавчальної організації, репрезентацію дії якої відтворено за оригінальною концептуальноаналітичною моделлю при розмежуванні iї архітектури на засадах інноваційного розвитку. Представлена модель самонавчальної організації, новизна якої полягає в систематизації та уточненні вимог до основних елементів організації та у відображенні взаємозв'язків між ними. Розроблено механізм створення й використання знань самонавчальної організації. Це підвищить іії конкурентоспроможність із позицій стратегічного підходу та розширить конкурентні позиції на ринку.

Практична значимість. Практичне застосування наукових розробок і рекомендацій авторів дає змогу підвищити інноваційність і ефективність структуроутворюючих організацій національної інноваційної системи.

Ключові слова: інноваційний розвиток, самонавчальна організація, неперервне навчання, інтелектуальний потенціал, людський капітал, менеджмент знань

Recommended for publication by N. Y. Marynenko, Doctor of Economic Sciences. The manuscript was submitted 26.12.20. 